\title{
IMPLEMENTASI KRIPTOGRAFI KLASIK PADA KOMUNIKASI BERBASIS TEKS
}

\author{
M. Miftakul Amin ${ }^{1}$ \\ ${ }^{1}$ Jurusan Teknik Komputer, Politeknik Negeri Sriwijaya Palembang \\ Jalan Srijaya Negara, Bukit Besar, Palembang 30139 \\ Telp. 0711 - 353414 Fax. 0711 - 355918 \\ website : http://polsri.ac.id \\ ${ }^{1}$ miftakul_a@polsri.ac.id
}

\begin{abstract}
Abstrak: Kemajuan di bidang komunikasi data dan jaringan komputer telah memungkinkan ribuan orang untuk melakukan komunikasi dengan beragam teknologi perangkat keras dan perangkat lunak. Di sisi lain terdapat ancaman yang membayangi kemajuan tersebut, yaitu aspek keamanan data dan informasi. Sistem keamanan data diperlukan untuk melindungi data dan informasi yang ditransmisikan melalui jaringan komunikasi. Salah satu mekanisme untuk menyediakan layanan keamanan data adalah teknik kriptografi. Dalam kriptografi, data yang dikirimkan melalui jaringan akan disamarkan sedemikian rupa dengan teknik enkripsi sehingga kalaupun data itu bisa dibaca maka tidak bisa dimengerti oleh pihak yang tidak berhak. Data yang akan dikirimkan dan belum mengalami penyandian dikenal dengan istilah plaintext, dan setelah disamarkan dengan suatu cara penyandian, maka plaintext ini akan berubah menjadi ciphertext. Sebelum adanya komputer, kriptografi dilakukan dengan algoritma berbasis karakter. Terdapat sejumlah algoritma yang tercatat dalam sejarah kriptografi, algoritma-algoritma tersebut sering diistilahkan dengan algoritma kriptografi klasik. Pada penelitian ini diimplementasikan kriptografi klasik sebagai metode untuk melakukan proses enkripsi dan dekripsi data teks yang dikirimkan melalui aplikasi chat. Dari proses pengujian diperoleh bahwa proses enkripsi dan dekripsi dapat menjaga kerahasiaan data. Kata Kunci: kriptografi klasik, aplikasi chat
\end{abstract}

\begin{abstract}
Progress in the field of data communications and computer networks has enabled thousands of people to communicate with a variety of technology hardware and software. On the other hand there is a threat that overshadows the progress, namely the security aspects of data and information. Data security system is needed to protect the data and information that is transmitted over a communications network. One mechanism for providing data security services are cryptographic techniques. In cryptography, the data that is sent over the network will be disguised in such a way encryption techniques so that the data can be read even if it can not be understood by unauthorized parties. Data to be transmitted and has not experienced known as The term plaintext encryption, and after camouflaged with an encryption method, then it will turn into a plaintext ciphertext. Before the advent of computers, cryptography is done with a character-based algorithms. There are a number of algorithms that are recorded in the history of cryptography, algorithms are often termed classical cryptography algorithms. In this study classical cryptography implemented as a method to perform the encryption and decryption of data
\end{abstract}

that is sent via text chat application. Of the testing process is obtained that the encryption and decryption process to maintain the confidentiality of the data.

Keywords: classical cryptography, chat application

\section{PENDAHULUAN}

Komunikasi di era teknologi informasi tidak lagi harus dilakukan dengan cara bertemu langsung atau bertatap muka. Komunikasi dapat dilakukan dengan beragam bantuan baik perangkat keras maupun perangkat lunak. Salah satu bentuk komunikasi yang sering dilakukan adalah menggunakan teks. Dengan berkirim pesan melalui teks, pesan dapat sampai dari sisi pengirim ke sisi penerima. Pengiriman informasi melalui teks dapat dilakukan dengan fasilitas e-mail, chatting, sms, dan bentuk komunikasi lain berbasis teks. 
Salah satu bentuk komunikasi berbasis teks yang banyak digunakan di social media adalah aplikasi chatting. Layanan web seperti facebook dan yahoo juga menyediakan fasilitas chatting untuk berkirim pesan dengan menggunakan jaringan internet.

Aplikasi chatting banyak dilakukan karena penggunaannya yang relatif mudah, serta dalam keadaan yang sibuk masih tetap dapat memanfaatkan aplikasi tersebut. Penggunaan layanan seperti yahoo messenger atau facebook messenger membutuhkan koneksi internet secara terus menerus. Pada kenyataannya tidak semua komputer yang ada baik di kantor maupun rumah mempunyai koneksi ke internet. Pada kebanyakan komputer yang ada di perkantoran sebagian masih terhubung dalam jaringan Local Area Network (LAN). Sehingga perlu adanya sebuah layanan aplikasi chatting yang dapat berjalan dalam sebuah jaringan.

Pesan yang dikirimkan antar pengguna aplikasi chatting perlu diberikan layanan keamanan data, sehingga hanya orang-orang yang memiliki otoritas saja yang dapat mengetahui isi pesan yang disampaikan tersebut. Walaupun komunikasi dilakukan dalam mode offline hanya melalui jaringan LAN tetapi tidak menutup kemungkinan jalur komunikasi tersebut disusupi oleh cracker yang dapat mengakses pesan yang ditransmisikan. Perlu dibuat mekanisme supaya pesan yang dikirimkan dapat terjaga kerahasiaannya.

Dengan demikian permasalahan yang akan dimunculkan dalam penelitian ini adalah:

1. Bagaimana membangun sebuah aplikasi chatting dengan memanfaatkan jaringan Local Area Network (LAN)?
2. Bagaimana teknik mengamankan pesan pada aplikasi chatting sehingga dapat menjamin kerahasiaan pesan yang dikirimkan?

\section{TINJAUAN PUSTAKA}

Kriptografi (Cryptography) berasal dari bahasa Yunani, terdiri dari dua suku kata yaitu kripto dan graphia. Kripto artinya menyembunyikan, sedangkan graphia artinya tulisan. Kriptografi adalah ilmu yang mempelajari teknik-teknik matematika yang berhubungan dengan aspek keamanan informasi, seperti kerahasian data, keabsahan data, integritas data, serta autentikasi data. Tetapi tidak semua aspek keamanan informasi dapat diselesaikan dengan kriptografi [1].

Kriptografi dapat pula diartikan sebagai ilmu atau seni untuk menjaga keamanan pesan. Ketika suatu pesan dikirim dari suatu tempat ke tempat lain, isi pesan tersebut mungkin dapat disadap oleh pihak lain yang tidak berhak untuk mengetahui isi pesan tersebut. Untuk menjaga pesan, maka pesan tersebut dapat diubah menjadi sebuah kode yang tidak dapat dimengerti pihak lain [2].

Enkripsi adalah sebuah proses penyandian yang melakukan perubahan sebuah kode (pesan) dari yang bisa dimengerti (plaintext) menjadi sebuah kode yang tidak bisa dimengerti (chipertext). Sedangkan proses kebalikannya untuk mengubah cipertext menjadi plaintext disebut dekripsi. Proses enkripsi dan deskripsi memerlukan suatu mekanisme dan kunci tertentu [3]. Kriptografi adalah ilmu mengenai teknik enkripsi dimana data diacak menggunakan suatu kunci enkripsi menjadi sesuatu yang sulit dibaca oleh seseorang yang tidak memiliki kunci dekripsi [4]. Dekripsi menggunakan kunci dekripsi mendapatkan kembali data asli. Proses enkripsi dilakukan 
menggunakan suatu algoritma dengan beberapa parameter. Biasanya algoritma tidak dirahasiakan, bahkan enkripsi yang mengandalkan kerahasiaan algoritma dianggap sesuatu yang tidak baik. Rahasia terletak di beberapa parameter yang digunakan, jadi kunci ditentukan oleh parameter.

Algoritma kriptografi klasik memiliki ciri diantaranya berbasis karakter dan menggunakan kunci simetri. Dalam kriptografi klasik, teknik enkripsi yang digunakan adalah enkripsi simetris dimana kunci dekripsi sama dengan kunci enkripsi seperti dapat dilihat pada Gambar 1.

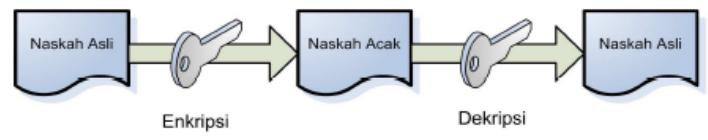

Gambar 1. Proses Enkripsi dan Dekripsi

Salah satu algoritma klasik adalah Caesar chipper. Dalam kriptografi klasik, secara umum dapat dikelompokkan dalam dua model yaitu menggunakan tekik substitusi dan transposisi [6]. Teknik substitusi dilakukan dengan mengganti salah satu karakter yang ada dalam sebuah teks menggunakan karakter yang lain. Teknik yang termasuk dalam kategori substitusi adalah kriptografi Caesar. Teknik yang digunakan adalah dengan memetakan karakter A-Z ke dalam deretan index numeric seperti Gambar 2.

\begin{tabular}{|c|c|c|c|c|c|c|c|c|c|c|c|c|}
\hline A & B & C & D & E & F & G & H & I & J & K & L & M \\
\hline 0 & 1 & 2 & 3 & 4 & 5 & 6 & 7 & 8 & 9 & 1 & 1 & 1 \\
& & & & & & & & & & 0 & 1 & 2 \\
\hline N & O & P & Q & R & S & T & U & V & W & X & Y & Z \\
\hline 1 & 1 & 1 & 1 & 1 & 1 & 1 & 2 & 2 & 2 & 2 & 2 & 2 \\
3 & 4 & 5 & 6 & 7 & 8 & 9 & 0 & 1 & 2 & 3 & 4 & 5 \\
\hline
\end{tabular}

Algoritma Caesar chipper melakukan pergeseran karakter sebagai kunci $(k)$ dengan rentang nilai $k$ sebesar $1-25$, yang secara matematis dijabarkan dalam bentuk:
Untuk proses enkripsi

$$
C=E(k, p)=(p+k) \bmod 26
$$

Sedangkan untuk melakukan proses dekripsi

$$
P=D(k, c)=(C-k) \bmod 26
$$

Dari sudut pandang aplikasi, koneksi antar komputer yang terbentuk adalah koneksi dari socket ke socket. Socket adalah dua buah nilai yang mengidentifikasi setiap endpoint sebuah alamat IP dan sebuah nomor port [5]. Untuk dapat berkomunikasi antara dua komputer, masingmasing port harus dalam kondisi terbuka. Tahapan dalam melakukan koneksi antara komputer client dan server dapat dijabarkan sebagai berikut .

1) Server membuat sebuah socket dengan menggunakan karakter unik (misalnya dengan penentuan alamat IP dan nomor port), yang dapat diidentifikasi dan ditemukan oleh client, pada saat ini server telah memasuki kondisi listening. Kondisi listening adalah keadaan di mana server dalam kondisi siap untuk menerima permintaan servis dari client.

2) Client membuat socket, mencari nama atau alamat socket server dan kemudian “menyambungkannya” untuk menginisialisasi sebuah komunikasi.

3) Setelah inisialisasi dilakukan maka client dan server sudah bisa saling mengirimkan data dan menerima data.

Dalam pengembangan sistem yang akan dibangun digunakan bahasa pemrograman Basic, merupakan bahasa pemrograman yang banyak digunakan oleh programmer pemula. Bahasa ini mudah digunakan dan tidak banyak ketentuan yang mengikat, dibandingkan bahasa prosedural seperti Bahasa $C$ atau Pascal. Pada Visual Basic perancangan aplikasi dimulai dari mendefinisikan tujuan program, merancang keluaran sebagai 
media komunikasi dengan pengguna, dan menuliskan kode programnya [7].

Pemrograman dengan Visual Basic banyak menggunakan istilah obyek. Obyek-obyek digunakan pada layer untuk melakukan pengaturan properti terhadap obyek yang digambarkan. Pada saat program dijalankan, dituliskan metode-metode terhadap obyek tersebut sesuai dengan tujuan program. Untuk membuat sebuah program aplikasi dengan Visual Basic, dimulai dengan membuat form terlebih dahulu, kemudian dibuat file dan modul lain. Setelah komponen dipadukan dan kode selesai ditulis, dilanjutkan dengan membuat proyek menjadi file yang dapat dieksekusi [8].

Penelitian dengan tema komunikasi berbasis teks (chatting) telah banyak dilakukan, diantaranya penelitian yang dilakukan oleh Setiawan [9] yang telah mengembangkan aplikasi chatting menggunakan jaringan LAN. Aplikasi dapat digunakan oleh beberapa orang secara serentak (multiuser) dan didalamnya juga terdapat fasilitas untuk berkirim file sehingga menjadi komunikasi antara user dapat berjalan lebih efektif. Sisi lemah dari aplikasi ini adalah masih belum adanya fasilitas history yang mencatat isi informasi komunikasi yang telah dilakukan sehingga dapat dibuka kembali pada sesi komunikasi berikutnya. Penelitian yang dilakukan Zakaria [10] juga telah mengembangkan teknologi komunikasi chatting menggunakan media komputer dan handphone melalui koneksi Bluetooth. Dalam sistem yang dikembangkan telah terdapat fasilitas history yang menyimpan informasi komunikasi yang telah berlangsung sebelumnya.

Penelitian tentang penyandian data pernah dilakukan oleh Hasugian [11] yang mengembangkan teknik penyandian hill cipher pada penyimpanan basis data. Informasi yang tersimpan di dalam basis data dibagi menjadi beberapa blok kemudian dilakukan proses enkripsi. Sistem dikembangkan dengan bahasa pemrograman Visual Basic 6 untuk proses penyandian di dalam basis data. Penggunaan kriptografi klasik lainnya juga pernah dilakukan oleh Fairuzabadi [12] dan Sasongko [13] yang telah mengembangkan sistem keamanan data menggunakan bahasa pemrograman Delphi dan bahasa $\mathrm{C} / \mathrm{C}++$. Penelitian ini lebih mengedepankan aspek pemrograman dengan memetakan formula matematis ke dalam bahasa pemrograman.

Dalam penelitian ini yang dilakukan adalah mengembangkan sebuah aplikasi chatting dengan menggunakan teknik kriptografi klasik. Sehingga informasi yang dikirimkan oleh user yang saling berkomunikasi di dalam sistem dapat terjaga kerahasiaan datanya.

\section{METODE PENELITIAN}

Dalam proses komunikasi berbasis teks yang dikembangkan, pesan dikirim dalam bentuk teks yang telah dienkripsi (chipertext), ketika pesan sampai pada sisi penerima pesan dikemas dalam pesan yang telah didekripsi (plaintext) seperti dapat dilihat pada Gambar 3. Pesan tersebut dikirimkan melalui jaringan Local Area Network (LAN). Sistem ini merupakan aplikasi chat sederhana yang pengiriman datanya pesan telah dienkripsi menggunakan algoritma Caesar chipper. Sistem ini mengizinkan 2 orang user untuk berkomunikasi melalui TCP/IP.

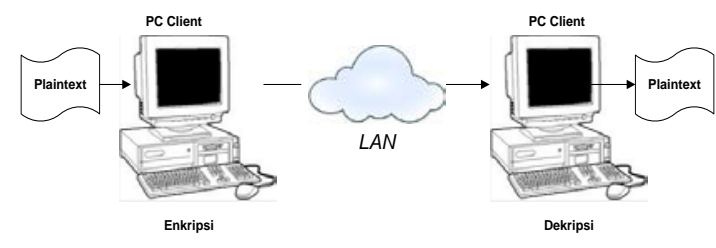

Gambar 3. Rancangan Sistem Yang Dibangun 
Secara umum layanan yang ada di dalam aplikasi yang dibangun dapat dilihat pada Gambar 4, terdapat fasilitas untuk mengisi nama dan melakukan koneksi ke jaringan LAN. Pada saat melakukan proses pengiriman pesan, selalu melibatkan enksripsi yang didalamnya terdapat metode/fungsi untuk melakukan enkripsi. Dan pada proses pembacaan pesan selalu menggunakan use case dekripsi untuk mengembalikan kembali pesan yang telah dienkripsi sehingga terbaca oleh sistem.

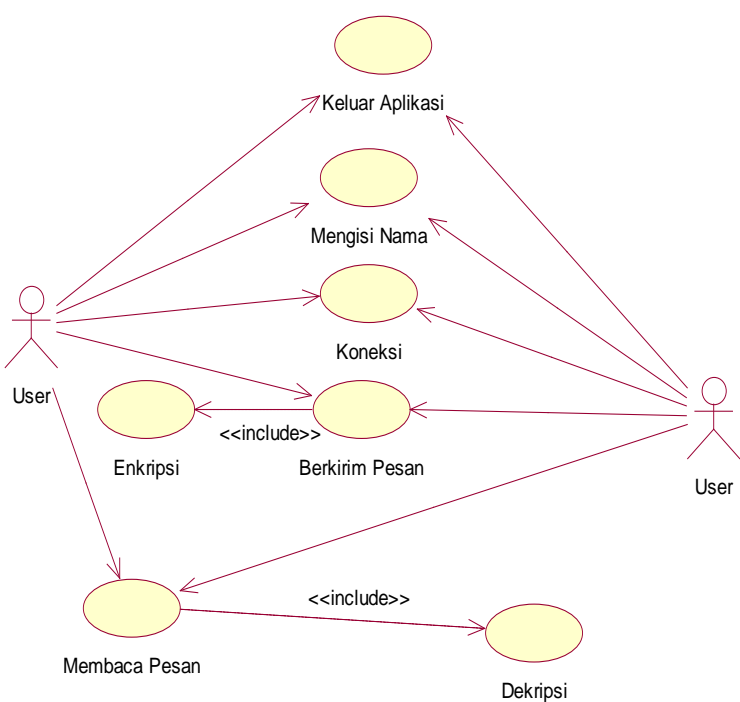

Gambar 4. Use Case Diagram Sistem

\section{HASIL DAN PEMBAHASAN}

Penelitian ini menghasilkan perangkat lunak yang dibangun dalam lingkungan client/server dengan model visual/desktop application.

Aplikasi yang dibangun menghasilkan 2 buah aplikasi, 1 buah bertindak sebagai server dan 1 buah sebagai client. Aplikasi server menunggu (listening) permintaan komunikasi dari client. Demikian juga client harus proaktif untuk memulai komunikasi. Pada awal kedua aplikasi diaktifkan masing-masing terdapat indikator lampu berwarna merah, yang menandakan bahwa komunikasi antara client dan server belum terbentuk seperti dapat dilihat pada Gambar 5.

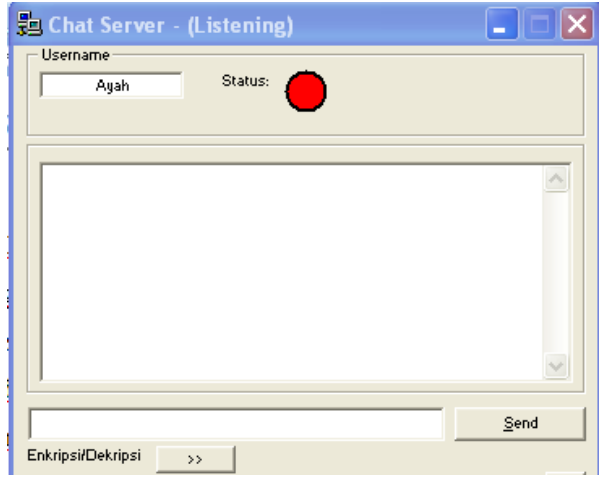

(a) Posisi server menunggu request

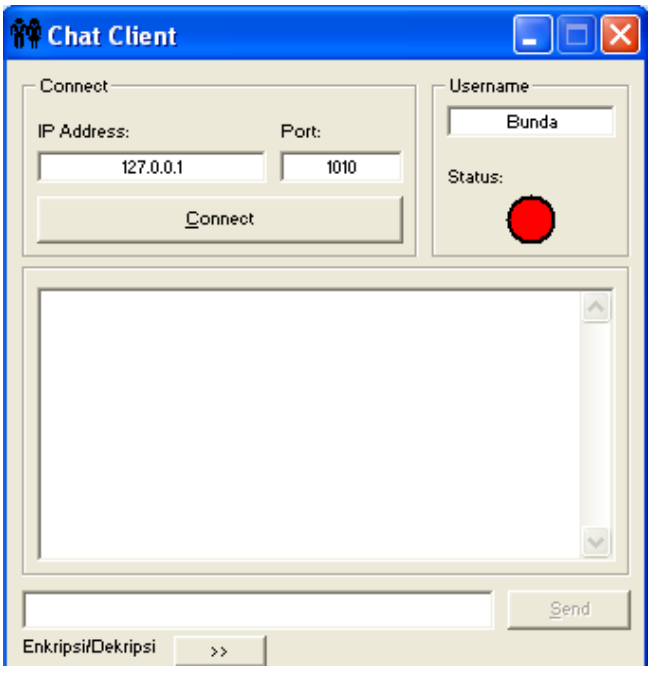

(b) Posisi client pertama kali aktif

Gambar 5. Posisi Aplikasi Client dan Server Pada Saat

Diaktifkan Pertama Kali.

Setelah komunikasi terbentuk kedua lampu indikator pada masing-masing aplikasi akan berwarna hijau yang menandakan bahwa komunikasi telah terbentuk. Teks yang terkirim pada aplikasi akan dienkripsi menggunakan algoritma Caesar Chipper dengan pergeseran sebanyak 3 karakter. Seperti dapat dilihat pada Gambar 6. Di bagian bawah dari panel aplikasi terdapat teks yang terbaca (plaintext) sehingga setiap kali sesi berkirim pesan dilakukan otomatis akan didekripsi sehingga terbaca pada sisi penerima. Pada proses komunikasi secara runtime dapat diubah parameter pergeseran kunci dari algoritma Caesar chipper pada Gambar 6 terlihat menggunakan pergeseran kunci sebanyak 3. 


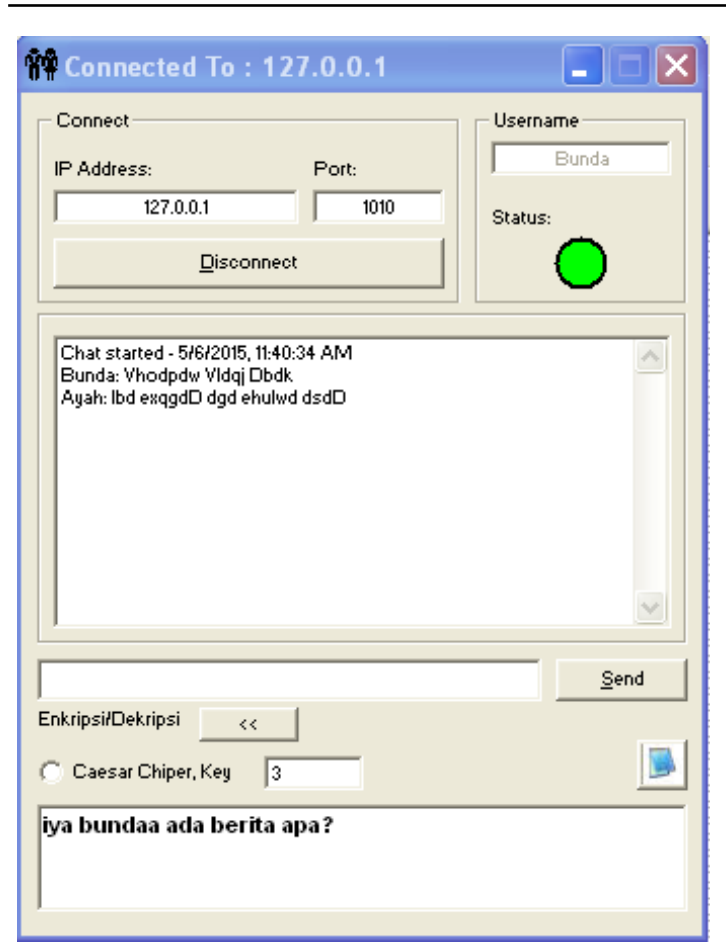

(a) Teks Pada Aplikasi Client

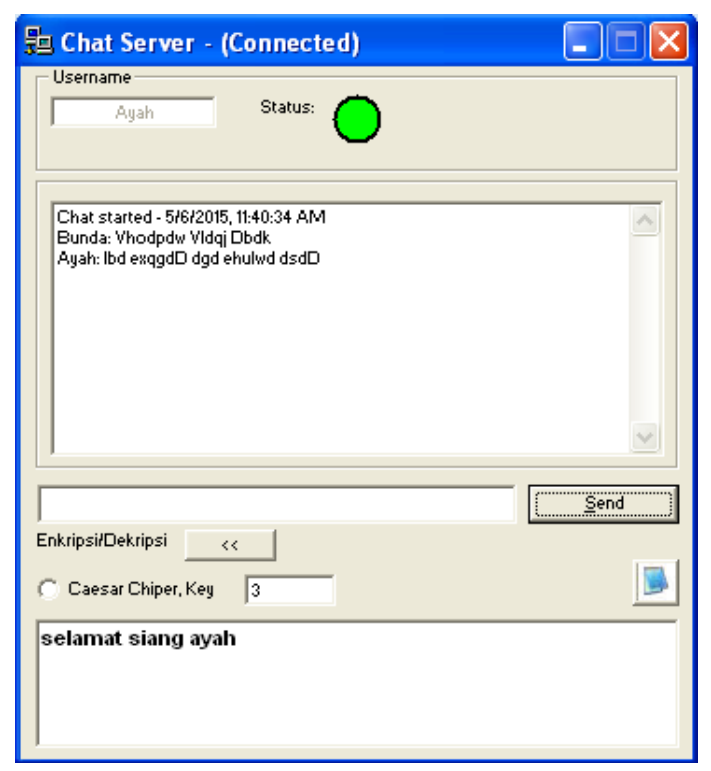

(b) Teks Pada Aplikasi Server

Gambar 6. Pola Pengiriman Teks

Pada bagian bawah dari aplikasi client dan server juga terdapat satu buah file teks yang berisi hasil dari proses berkirim pesan dalam bentuk plaintext. Sehingga setelah semua sesi komunikasi berbasis teks telah selesai dilakukan dapat dilihat secara menyeluruh komunikasi yang telah terjadi. Hasil sesi percakapan disimpan dalam satu buah file teks sehingga dapat dibuka dengan mudah menggunakan aplikasi text editor seperti Notepad.

Beberapa pengujian yang dilakukan dari sisi aplikasi menggunakan metode black box dapat dijabarkan pada Tabel 1. Pengujian black box (black box testing) adalah salah satu metode pengujian perangkat lunak yang berfokus pada sisi fungsionalitas, khususnya pada input dan output aplikasi (apakah sudah sesuai dengan apa yang diharapkan atau belum). Tahap pengujian atau testing merupakan salah satu tahap yang harus ada dalam sebuah siklus pengembangan perangkat lunak (selain tahap perancangan atau desain).

Tabel 1. Pengujian Black Box Aplikasi Chatting

\begin{tabular}{|c|c|c|c|c|c|}
\hline No. & $\begin{array}{l}\text { Skenario } \\
\text { Pengujian }\end{array}$ & $\begin{array}{l}\text { Test } \\
\text { Case }\end{array}$ & $\begin{array}{l}\text { Hasil yang } \\
\text { diharapkan }\end{array}$ & $\begin{array}{c}\text { Hasil } \\
\text { Pengujian }\end{array}$ & $\begin{array}{l}\text { Sim- } \\
\text { pulan }\end{array}$ \\
\hline 1 & $\begin{array}{l}\text { Mengisi-kan } \\
\text { nama sebagai } \\
\text { identitas user } \\
\text { yang } \\
\text { menggunakan } \\
\text { aplikasi dan } \\
\text { melakukan } \\
\text { koneksi }\end{array}$ & Nama: - & $\begin{array}{c}\text { Sistem akan } \\
\text { memberikan } \\
\text { respon } \\
\text { bahwa } \\
\text { proses } \\
\text { koneksi } \\
\text { untuk mulai } \\
\text { komunikasi } \\
\text { dapat } \\
\text { dilakukan } \\
\text { setelah user } \\
\text { mengisikan } \\
\text { nama. }\end{array}$ & $\begin{array}{l}\text { Sesuai } \\
\text { harapan }\end{array}$ & Valid \\
\hline 2 & $\begin{array}{l}\text { Mengosong- } \\
\text { kan semua } \\
\text { isian data } \\
\text { pesan, } \\
\text { kemudian } \\
\text { menkan } \\
\text { tombol Send. }\end{array}$ & Pesan: - & \begin{tabular}{|} 
Sistem akan \\
menolak \\
proses \\
pengiriman \\
pesan \\
dengan \\
memuncul- \\
kan \\
informasi \\
bahwa \\
"Pesan \\
Masih \\
Kosong”
\end{tabular} & $\begin{array}{c}\text { Sesuai } \\
\text { harapan }\end{array}$ & Valid \\
\hline 3 & $\begin{array}{l}\text { Menginputka } \\
\text { n pesan yang } \\
\text { akan dikirim- } \\
\text { kan kepada } \\
\text { penerim. } \\
\text { Pesan yang } \\
\text { dikirim-kan } \\
\text { adalah sapaan } \\
\text { 'selamat } \\
\text { siang'. } \\
\text { Ketika pesan } \\
\text { sampai pada } \\
\text { sisi penerima } \\
\text { akan } \\
\text { dienkripsi } \\
\text { menjadi } \\
\text { 'vhodpdw } \\
\text { vldqj’ }\end{array}$ & $\begin{array}{c}\text { Pesan: } \\
\text { selamat } \\
\text { siang }\end{array}$ & \begin{tabular}{|c} 
Sistem akan \\
melakukan \\
enkripsi \\
pesan \\
mengguna- \\
kan \\
algoritma \\
Caesar \\
chipper \\
dengan \\
pergeseran \\
kunci \\
sebanyak \\
k=3
\end{tabular} & $\begin{array}{c}\text { Sesuai } \\
\text { harapan }\end{array}$ & valid \\
\hline
\end{tabular}


Jurnal Pseudocode, Volume III Nomor 2, September 2016, ISSN 2355-5920

Dari sisi content informasi aplikasi yang dikembangkan juga dilakukan pengujian untuk melihat sejauh mana kemampuan module kriptografi klasik yang ditanamkan di dalam sistem. Pengujian yang dilakukan adalah dengan menggunakan input berupa plaintext ataupun chipertext untuk melihat output yang dihasilkan. Algoritma Caesar Cipher menggunakan operasi modulus atau sisa bagi. Operasi pembagian $\mathrm{a} / \mathrm{n}$ pada bilangan integer diinterpretasikan memiliki 2 buah keluaran yaitu hasil bagi (q/quotion) dan sisa bagi (r/remainder). Relasi keempat bilangan tersebut diekspresikan dalam persamaan [3]:

$$
a=q \times n+r
$$

Untuk melihat cara kerja dari algoritma Caesar cipher dapat digunakan formula 1) dan formula 2) untuk proses enkripsi dan dekripsi. Sebagai contoh jika terdapat sebuah plaintext "SELAMAT SIANG”, maka proses enkripsi dan dekripsi dapat dilakukan dengan langkah-langkah seperti pada Tabel 2 dan Tabel 3. Sementara pemetaan karakter dapat dilihat pada Gambar 7.

\begin{tabular}{|c|c|c|c|c|c|c|c|c|c|c|c|c|}
\hline A & B & C & D & E & F & G & H & I & J & K & L & M \\
\hline 0 & 1 & 2 & 3 & 4 & 5 & 6 & 7 & 8 & 9 & 1 & 1 & 1 \\
0 & 1 & 2 \\
\hline N & O & P & Q & R & S & T & U & V & W & X & Y & Z \\
\hline 1 & 1 & 1 & 1 & 1 & 1 & 1 & 2 & 2 & 2 & 2 & 2 & 2 \\
3 & 4 & 5 & 6 & 7 & 8 & 9 & 0 & 1 & 2 & 3 & 4 & 5 \\
\hline 19
\end{tabular}

Tabel 2 Proses Enkripsi

\begin{tabular}{|c|c|c|}
\hline \multicolumn{3}{|c|}{$\begin{array}{l}\text { Plaintext : SELAMAT SIANG } \\
\text { Kunci }(\mathrm{k}): 3 \\
\text { Proses Enkripsi }\end{array}$} \\
\hline $\mathrm{P}$ & Index & $\mathrm{C}=(\mathrm{P}+\mathrm{k}) \bmod 26$ \\
\hline $\mathrm{S}$ & 18 & $\begin{array}{l}(18+3) \bmod 26=21 \bmod 26= \\
21 \rightarrow \mathrm{V}\end{array}$ \\
\hline $\mathrm{E}$ & 4 & $\begin{array}{l}(4+3) \bmod 26=7 \bmod 26= \\
7 \rightarrow H\end{array}$ \\
\hline $\mathrm{L}$ & 11 & $\begin{array}{l}(11+3) \bmod 26=14 \bmod 26= \\
14 \rightarrow 0\end{array}$ \\
\hline A & 0 & $\begin{array}{l}(0+3) \bmod 26=3 \bmod 26= \\
3 \rightarrow D\end{array}$ \\
\hline
\end{tabular}

\begin{tabular}{|c|c|c|}
\hline $\mathrm{M}$ & 12 & $\begin{array}{l}(12+3) \bmod 26=15 \bmod 26= \\
15 \rightarrow P\end{array}$ \\
\hline $\mathrm{A}$ & 0 & $\begin{array}{l}(0+3) \bmod 26=3 \bmod 26= \\
3 \rightarrow D\end{array}$ \\
\hline $\mathrm{T}$ & 19 & $\begin{array}{l}(19+3) \bmod 26=22 \bmod 26= \\
22 \rightarrow W\end{array}$ \\
\hline $\mathrm{S}$ & 18 & $\begin{array}{l}(18+3) \bmod 26=21 \bmod 26= \\
21 \rightarrow V\end{array}$ \\
\hline I & 8 & $\begin{array}{l}(8+3) \bmod 26=11 \bmod 26= \\
11 \rightarrow L\end{array}$ \\
\hline $\mathrm{A}$ & 0 & $\begin{array}{l}(0+3) \bmod 26=3 \bmod 26= \\
3 \rightarrow D\end{array}$ \\
\hline $\mathrm{N}$ & 13 & $\begin{array}{l}(13+3) \bmod 26=16 \bmod 26= \\
16 \rightarrow Q\end{array}$ \\
\hline G & 6 & $\begin{array}{l}(\underset{9 \rightarrow J}{6+3}) \bmod 26=9 \bmod 26= \\
=\end{array}$ \\
\hline
\end{tabular}

Sehingga diperoleh proses enkripsi

Plaintext : SELAMAT SIANG

Ciphertext : VHODPDW VLDQJ

Tabel 3 Proses Dekripsi

\begin{tabular}{|c|c|l|}
\hline \multicolumn{3}{|c|}{$\begin{array}{l}\text { Ciphertext }: \text { VHODPDW VLDQJ } \\
\text { Kunci (k) }: 3\end{array}$} \\
Proses Dekripsi \\
\hline C & Index & \multicolumn{1}{c|}{$\mathrm{P}=(\mathrm{C}-\mathrm{k}) \bmod 26$} \\
\hline $\mathrm{V}$ & 21 & $\begin{array}{l}(21-3) \bmod 26=18 \bmod 26= \\
18 \rightarrow \mathrm{S}\end{array}$ \\
\hline $\mathrm{H}$ & 7 & $\begin{array}{l}(7-3) \bmod 26=4 \bmod 26= \\
4 \rightarrow \mathrm{E}\end{array}$ \\
\hline $\mathrm{O}$ & 14 & $\begin{array}{l}(14-3) \bmod 26=11 \bmod 26= \\
11 \rightarrow \mathrm{L}\end{array}$ \\
\hline $\mathrm{D}$ & 3 & $\begin{array}{l}(3-3) \bmod 26=0 \bmod 26= \\
0 \rightarrow \mathrm{A}\end{array}$ \\
\hline $\mathrm{P}$ & 15 & $\begin{array}{l}(15-3) \bmod 26=12 \bmod 26= \\
12 \rightarrow \mathrm{M}\end{array}$ \\
\hline $\mathrm{D}$ & 3 & $\begin{array}{l}(3-3) \bmod 26=0 \bmod 26= \\
0 \rightarrow \mathrm{A}\end{array}$ \\
\hline $\mathrm{W}$ & 22 & $\begin{array}{l}(22-3) \bmod 26=19 \bmod 26= \\
19 \rightarrow \mathrm{T}\end{array}$ \\
\hline $\mathrm{V}$ & 21 & $\begin{array}{l}(21-3) \bmod 26=18 \bmod 26= \\
18 \rightarrow \mathrm{S}\end{array}$ \\
\hline $\mathrm{L}$ & 11 & $\begin{array}{l}(11-3) \bmod 26=8 \bmod 26= \\
8 \rightarrow \mathrm{I}\end{array}$ \\
\hline $\mathrm{D}$ & 3 & $\begin{array}{l}(3-3) \bmod 26=0 \bmod 26= \\
0 \rightarrow \mathrm{A}\end{array}$ \\
\hline $\mathrm{Q}$ & 16 & $\begin{array}{l}(16-3) \bmod 26=13 \bmod 26= \\
13 \rightarrow \mathrm{N}\end{array}$ \\
\hline $\mathrm{J}$ & 9 & $\begin{array}{l}(9-3) \bmod 26=6 \bmod 26= \\
6 \rightarrow \mathrm{G}\end{array}$ \\
\hline
\end{tabular}

Sehingga diperoleh proses dekripsi

Ciphertext : VHODPDW VLDQJ

Plaintext : SELAMAT SIANG

Proses ujicoba module kriptografi klasik Caesar Cipher untuk beberapa teks dapat dilihat pada Tabel 4. 
Jurnal Pseudocode, Volume III Nomor 2, September 2016, ISSN 2355-5920

\begin{tabular}{|c|c|c|l|l|}
\hline \multicolumn{7}{|c|}{ Tabel 4. Pengujian Kriptografi } \\
\hline Enkripsi & Chipertext & Dekripsi & Berhasil & Gagal \\
\hline $\begin{array}{c}\text { Selamat } \\
\text { siang }\end{array}$ & $\begin{array}{c}\text { vhodpdw } \\
\text { vldqj }\end{array}$ & $\begin{array}{c}\text { Selamat } \\
\text { siang }\end{array}$ & $\checkmark$ & \\
\hline $\begin{array}{c}\text { Apa } \\
\text { kabar }\end{array}$ & dsd ndedu & $\begin{array}{c}\text { Apa } \\
\text { kabar }\end{array}$ & $\checkmark$ & \\
\hline Sehat & vhkdw & Sehat & $\checkmark$ & \\
\hline $\begin{array}{c}\text { Yang } \\
\text { diperoleh }\end{array}$ & $\begin{array}{c}\text { bdqj } \\
\text { glshurohk }\end{array}$ & $\begin{array}{c}\text { Yang } \\
\text { diperoleh }\end{array}$ & $\checkmark$ & \\
\hline Exotic & harwlf & Exotic & $\checkmark$ & \\
\hline Zigzag & cljcdj & Zigzag & $\checkmark$ & \\
\hline
\end{tabular}

\section{SIMPULAN}

Setelah penelitian ini selesai dilakukan, selanjutnya dapat disimpulkan bahwa untuk membangun aplikasi komunikasi berbasis teks dapat dibangun aplikasi chatting menggunakan pemrograman socket, dengan arsitektur aplikasi client/server. Algoritma Caesar chipper dapat digunakan untuk melakukan enkripsi/dekripsi pesan yang dikirimkan dalam aplikasi chatting.

Untuk penelitian lanjutan dapat dikembangkan dengan membuat komunikasi chatting di dalam sebuah group, sehingga banyak user yang dapat bergabung dalam aplikasi untuk berkirim pesan. Dari sisi metode enkripsi dapat ditambahkan beberapa pilihan teknik enkripsi sehingga akan menjadikan aplikasi semakin tangguh untuk menjaga kerahasiaan data.

\section{UCAPAN TERIMA KASIH}

Terimakasih kepada seluruh redaksi Jurnal Pseudocode yang telah memberi kesempatan, sehingga tulisan ini dapat dimuat.

\section{REFERENSI}

[1] Ariyus, D. (2006). "Kriptografi Keamanan Data dan Kriptografi”.Yogyakarta: Penerbit Andi Offset.

[2] Maulana, A., R. (2012). "Penerapan Algoritma WAKE Pada Aplikasi Chatting \& Internet Monitor Berbasis LAN”. Yogyakarta : STMIK Amikom Yogyakarta.

[3] Kurniawan, Y. (2004). "Kriptografi Keamanan Internet dan Jaringan Komunikasi”. Bandung: Penerbit Informatika.

[4] Kromodimoeljo, S. (2009). “Teori dan Aplikasi Kriptografi”. Jakarta: SPK IT Consulting

[5] Stevens, Richard W. (1998). “UNIX Network Programming Volume I, Networking APIs: Sockets and $X T I$ ”, Prentice-Hall,Inc.

[6] Stalling, W. (2006). "Cryptography and Network Security Principles and Practice Fifth Edition”. New York: Prentice Hall

[7] Putra, I. (2004). "Membangun Aplikasi Nyata Dengan Visual Basic 6.0”. Yogyakarta: Penerbit Andi.

[8] Nalwan, A. (2004). "Membuat Program Profesional Secara Cepat dengan VB". Jakarta: Penerbit Gramedia

[9] Setiawan, R. (2009). "Membangun Aplikasi Chatting Berbasis Multiuser Jurnal DASI Vol. 10 No. 1 Maret 2009". Yogyakarta: STMIK AMIKOM

[10] Zakaria, M. T.; Wijaya, D.S. (2009). "Aplikasi Chat pada Handphone dan Komputer dengan Media Bluetooth (Bluetooth Chat) Jurnal Teknologi InformasiAiti Vol. 6 No. 1 Februari 2009". Bandung: Universitas Kristen Maranatha

[11] Hasugian, H. A. (2013). "Implementasi Algoritma Hill Cipher Dalam Penyandian Data jurnal Pelita Informatika Budi Darma Vol. 4 No. 2 Agustus 2013". Medan: STMIK Budi Darma

[12] Fairuzabadi, M. (2010). "Implementasi Kriptografi Klasik Menggunakan Borland Delphi, Jurnal Dinamika Informatika Vol. 4 No. 2 September 2010". Yogyakarta: Universitas PGRI

[13] Sasongko, J. (2005). "Pengamanan Data Informasi Menggunakan Kriptografi Klasik, Jurnal Teknologi Informasi Dinamik Vol. 10 No. 3 September 2005". Semarang: Universitas Stikubang

[14] Sadikin, R. (2012). “Kriptografi Untuk Keamanan Jaringan”. Yogyakarta: Penerbit Andi Offset 